\title{
Accounting for Energy and Protein Reserve Changes in Predicting Diet-Allowable Milk Production in Cattle
}

\author{
L. O. Tedeschi, ${ }^{\star 1}$ S. Seo,† D. G. Fox, $†$ and R. Ruizł \\ *Department of Animal Science, Texas A\&M University, College Station 77843-2471 \\ †Department of Animal Science, Cornell University, Ithaca, NY 14853 \\ łElanco Animal Health, Guadalajara, Jalisco 44620, Mexico
}

\section{ABSTRACT}

Current ration formulation systems used to formulate diets on farms and to evaluate experimental data estimate metabolizable energy (ME)-allowable and metabolizable protein (MP)-allowable milk production from the intake above animal requirements for maintenance, pregnancy, and growth. The changes in body reserves, measured via the body condition score (BCS), are not accounted for in predicting $\mathrm{ME}$ and MP balances. This paper presents 2 empirical models developed to adjust predicted diet-allowable milk production based on changes in BCS. Empirical reserves model 1 was based on the reserves model described by the 2001 National Research Council (NRC) Nutrient Requirements of Dairy Cattle, whereas empirical reserves model 2 was developed based on published data of body weight and composition changes in lactating dairy cows. A database containing 134 individually fed lactating dairy cows from 3 trials was used to evaluate these adjustments in milk prediction based on predicted firstlimiting ME or MP by the 2001 Dairy NRC and Cornell Net Carbohydrate and Protein System models. The analysis of first-limiting ME or MP milk production without adjustments for BCS changes indicated that the predictions of both models were consistent $\left(\mathrm{r}^{2}\right.$ of the regression between observed and model-predicted values of 0.90 and 0.85 ), had mean biases different from zero (12.3 and 5.34\%), and had moderate but different roots of mean square errors of prediction (5.42 and 4.77 $\mathrm{kg} / \mathrm{d}$ ) for the $2001 \mathrm{NRC}$ model and the Cornell Net Carbohydrate and Protein System model, respectively. The adjustment of first-limiting ME- or MP-allowable milk to BCS changes improved the precision and accuracy of both models. We further investigated 2 methods of adjustment; the first method used only the first and last BCS values, whereas the second method used the mean of weekly BCS values to adjust ME- and MPallowable milk production. The adjustment to BCS

Received August 26, 2005.

Accepted July 11, 2006

${ }^{1}$ Corresponding author: luis.tedeschi@tamu.edu changes based on first and last BCS values was more accurate than the adjustment to BCS based on the mean of all BCS values, suggesting that adjusting milk production for mean weekly variations in BCS added more variability to model-predicted milk production. We concluded that both models adequately predicted the firstlimiting ME- or MP-allowable milk after adjusting for changes in BCS.

Key words: body condition score, fat mobilization, fat repletion, modeling

\section{INTRODUCTION}

Computer programs based on the NRC (2001) model formulate rations for lactating dairy cows by computing energy and protein requirements for an inputted milk production and then formulate a diet that will meet requirements for that amount of milk at the DMI predicted from BW and milk. Rations in early lactation are typically deficient in energy and assume the deficiency will be met by mobilization of body reserves. Then in mid- and late lactation, energy intake must exceed requirements for milk production to replenish body reserves before the next lactation. With current and proposed environmental regulations, precision feeding is needed to more accurately formulate diets to avoid under- or overfeeding nutrients (Cerosaletti et al., 2004) while optimizing milk and reproductive performance. Dairy nutrition models are being designed with these objectives (Tylutki and Fox, 2005). Precision ration formulation for dairy cows requires accounting for fluxes in body reserves when formulating diets. In addition, dairy nutrition models with the capability of accounting for body reserves can be used to more accurately evaluate experimental results in which milk response to dietary inputs is the variable of interest. Baldwin et al. (1987b,c) developed a mechanistic model of metabolism and digestion for lactating dairy cows and concluded that models can realistically simulate lactation and the partition of nutrients (Baldwin et al., 1987a).

Body weight changes reflect the use of energy reserves either to supplement ration deficiencies during 
early lactation or to store energy consumed above the requirements (Moe et al., 1972; NRC, 2001). The BW gain and loss after maturity is similar in composition to changes during growth (NRC, 2001) and can be used to predict changes in energy balance over the reproductive cycle (Reynoso-Campos et al., 2004). However, most dairy and beef producers monitor BCS changes in cows to manage energy reserves because frequent measurements of BW are not feasible under practical conditions. The Cornell Net Carbohydrate and Protein System (CNCPS; Fox et al., 2004) and the NRC (2000, 2001) models use the body reserves model as devised by Fox et al. (1999), which was developed from data on the chemical body composition and BCS of 106 mature beef cows of diverse breed types and BW. As applied to dairy cattle, the model was evaluated with the data of Otto et al. (1991) and accounted for 95\% of the variation in body fat, with only a $-1.6 \%$ bias (Fox et al., 1999). The model predicted $80 \mathrm{~kg}$ of BW change per BCS compared with $84.6 \mathrm{~kg}$ observed in Holstein cows slaughtered over the range of dairy BCS.

For lactating dairy cows, the CNCPS and NRC models estimate energy and protein requirements for maintenance and pregnancy, and the amount remaining above intake is used to estimate ME- and MP-allowable milk production, respectively (Fox et al., 2004). The changes in BCS are not accounted for in predicting $\mathrm{ME}$ and MP balances. The objective of this study was to develop and compare 2 empirical models to eliminate biases in energy retention by adjusting the predicted $\mathrm{ME}$ - and MP-allowable milk production after consecutive changes in observed BCS have been accounted for.

\section{MATERIALS AND METHODS}

\section{Model Development}

Two empirical models were developed to estimate milk production based on changes in BCS. Empirical reserves model 1 (ERM1) was based on the reserves model described by the NRC (2001), whereas empirical reserves model 2 (ERM2) was developed based on literature data on $\mathrm{BW}$ changes in lactating dairy cows.

Milk Energy and Body Content of Energy and Protein. For both empirical models, the energy contained in milk production is computed using milk fat and milk true protein contents, as described by the NRC (2001). This energy in milk (MkE), as shown in Equation [1], is assumed to be the $\mathrm{NE}_{\mathrm{L}}$ :

$$
\begin{aligned}
M k E_{i}= & 0.0929 \times M k F_{i}+0.0563 \\
& \times M_{k T P}+0.192
\end{aligned}
$$

where $\mathrm{MkE}_{i}$ is the energy content of milk ( $\mathrm{Mcal} / \mathrm{kg}$ ), $\mathrm{MkF}_{i}$ is the milk fat content $(\mathrm{g} / 100 \mathrm{~g}), \mathrm{MkTP}_{i}$ is the milk true protein content $(\mathrm{g} / 100 \mathrm{~g})$, and the subscript $i$ is the $i$ th time period.

The BCS is a 5- (Wildman et al., 1982) or 9-point (Cantrell et al., 1981; Herd and Sprott, 1986) scale system that is highly related to body fat in cows (Houghton et al., 1990; Buskirk et al., 1992; NRC, 2000, 2001). Other scale systems that are used around the world (CSIRO, 1990) can be interconverted. Because the body reserves model used by the NRC (2001) is based on that developed by the NRC (2000), a BCS scale of 1 to 9 is used. Equation [2] is used to convert a BCS scale of 1 to $8\left(\mathbf{B C S}_{[1-8]}\right)$, as used by the Commonwealth Scientific and Industrial Research Organisation (CSIRO, 1990), to a BCS scale of 1 to $5\left(\mathbf{B C S}_{[1-5]}\right)$ and Equation [3] converts $\mathrm{BCS}_{[1-5]}$ to a BCS scale of 1 to $9\left(\mathbf{B C S}_{[1-9]}\right)$, and vice versa. As adopted by the NRC (2000, 2001), shrunk BW (SBW) is computed from BW as shown in Equation [4] and empty BW (EBW) is estimated from SBW as shown in Equation [5], which is used to predict body reserves:

$$
\begin{aligned}
& B C S_{[1-5], i}=\frac{\left(B C S_{[1-8], i}-1\right) \times 4}{7}+1 \\
& B C S_{[1-9], i}=\left(B C S_{[1-5], i}-1\right) \times 2+1
\end{aligned}
$$

where $\mathrm{BCS}_{[1-5], i}$ is the $\mathrm{BCS}$ on a scale of 1 to $5, \mathrm{BCS}_{[1-}$ $8], i$ is the BCS on a scale of 1 to 8 , and $\mathrm{BCS}_{[1-9], i}$ is the BCS on a scale of 1 to 9 ,

$$
\begin{gathered}
S B W_{i}=B W_{i} \times 0.96 \\
E B W_{i}=S B W_{i} \times 0.851
\end{gathered}
$$

where $\mathrm{SBW}_{i}$ is shrunk $\mathrm{BW}(\mathrm{kg})$ and $\mathrm{EBW}_{i}$ is empty BW (kg).

Empirical Reserves Model 1. This model is based on the equations published by Fox et al. (1999) in which $\mathrm{BCS}_{[1-9]}$ and EBW are used to compute the amount of body fat (TF; Equation [6]) and protein (TP; Equation [7]):

$$
\begin{gathered}
T F_{i}=\left(0.037683 \times B C S_{[1-9], i}\right) \times E B W_{i} \\
T P_{i}=(0.200886- \\
\times E B W_{i}
\end{gathered}
$$

where $\mathrm{EBW}_{i}$ is empty $\mathrm{BW}(\mathrm{kg}), \mathrm{TF}_{i}$ is the amount of body fat (kg), BCS $[1-9], i$ is the BCS (on a scale of 1 to 9 ), and $\mathrm{TP}_{i}$ is the amount of body protein $(\mathrm{kg})$.

For mature lactating cows, a change in BW does not necessarily indicate changes in tissue reserves, and vice versa. Andrew et al. (1994) and Gibb et al. (1992) ana- 
lyzed slaughter data of dairy cows and reported as much as $40 \%$ variation in energy with no change in BW. This is likely because the gut fill varies from 2.5 (Komaragiri and Erdman, 1997) to $4 \mathrm{~kg} / \mathrm{kg}$ of increase in DMI (Chilliard et al., 1991), which may offset the weight loss attributable to tissue mobilization by an increase in DMI during early lactation. Because of this disconnection between actual BW and energy reserves, ERM1 uses BCS changes to estimate EBW and energy reserves.

As discussed by Fox et al. (1999), the database used at the NRC (2000) to develop the body reserves model indicated that the mean BW change associated with a BCS change was equivalent to $6.85 \%$ of the mean BW. The Commonwealth Scientific and Industrial Research Organisation (1990) uses $8 \%$ of the standard reference weight per change in $\mathrm{BCS}_{[1-8]}$, which is equivalent to $7 \%$ per change in $\mathrm{BCS}_{[1-9]}$. Therefore, a weight adjustment factor (WAF; Equation [8]) is computed from the BCS. Adjusted EBW values (aEBW; Equation [9]) are then computed for all other periods $(i \geq 2)$ based on their respective WAF values (Equation [8]), which are a function of the measured BCS for each period:

$$
\begin{gathered}
W A F_{i}=1-0.0685 \times\left(5-B C S_{[1-9], i}\right) \\
a E B W_{i}=\frac{E B W_{i=1}}{W A F_{i=1}} \times W A F_{i}
\end{gathered}
$$

where $\mathrm{BCS}_{[1-9], i}$ is the BCS (on a scale of 1 to 9 ).

The $\left(\mathrm{EBW}_{i=1} / \mathrm{WAF}_{i=1}\right)$ factor in Equation [9] computes the expected BW at BCS 5. The aEBW for each period $\left(\mathrm{aEBW}_{i}\right)$ is then used to assess the variation in tissue energy, which is added or subtracted from the tissue energy computed using the previous aEBW $\left(\mathrm{aEBW}_{i-1}\right)$ and Equations [6] and [7].

Empirical Reserves Model 2. This model is based on the equations derived by Otto et al. (1991) to compute the proportion of fat (Equation [10]) and protein (Equation [11]) in the 9th to 11th rib section of Holstein cows:

$$
\begin{gathered}
E E_{9^{\text {th }}-11^{\text {th }}}^{R i b}= \\
\frac{\left(16.44+12.65 \times B C S_{1-5}\right) \times\left(19.15+7.23 \times B C S_{1-5}\right)}{100} \\
\frac{\left(75.59-12.19 \times B C S_{1-5}\right) \times\left(19.15+7.23 \times B C S_{1-5}\right)}{100}
\end{gathered}
$$

where $\mathrm{EE}$ is ether extract (\%) and $\mathrm{BCS}_{[1-5]}$ is the BCS on a scale of 1 to 5 .

Conversion of the fat and protein contents from the 9th to the 11th rib to EBW is performed using the relationship between 9 th and 11 th rib and carcass com- position as developed by Hankins and Howe (1946; Equations [12] and [13], respectively) and from the carcass to EBW as derived by Garrett and Hinman (1969; Equations [14] and [15], respectively):

$$
\begin{aligned}
& E E_{\text {Carcass }}=2.82+0.77 \times E E_{9^{\text {th }}-11^{\text {th }}} \text { Rib } \\
& \text { Protein }_{\text {Carcass }}=5.98+0.66 \\
& \times \text { Protein }_{9}^{\text {th }}-11^{\text {th }} \text { Rib } \\
& E E_{E B W}=0.9246 \times E E_{\text {Carcass }}-0.647 \\
& \text { Protein }_{E B W}=0.7772 \times \text { Protein }_{\text {Carcass }}+0.713
\end{aligned}
$$

where $\mathrm{EE}$ is ether extract (\%) and EBW is empty BW.

Equation [16] was derived by combining Equations [3], [10], [12], and [14], and was solved for fat in the EBW. Similarly, Equation [17] was derived by combining Equations [3], [11], [13], and [15], and was solved for protein in the EBW:

$$
\begin{gathered}
T F_{i}= \\
\frac{\left(5.65+1.61 \times B C S_{1-9, i}+0.163 \times B C S_{1-9, i}^{2}\right) \times E B W_{i}}{100} \\
T P_{i}= \\
\frac{\left(13.9+0.651 \times B C S_{1-9, i}-0.113 \times B C S_{1-9, i}^{2}\right) \times E B W_{i}}{100} .
\end{gathered}
$$

Like the ERM1, the ERM2 assumes that changes in BW may reflect changes in gut fill and may not represent a true change in tissue. Therefore, BCS changes are used to compute changes in the tissue as a function of EBW. However, unlike the ERM1, the ERM2 relies on a fixed variation of EBW per change in BCS based on the analyses of Otto et al. (1991), who found that each unit of BCS change was associated with a $56-\mathrm{kg}$ change in live $\mathrm{BW}$. When converted to EBW, assuming a gut fill of $15 \%$, this change was $47.7 \mathrm{~kg}$ of EBW. Therefore, WAF values are compute for each interval based on the initial EBW and changes in the BCS using Equation [18] and aEBW are computed based on EBW and WAF values, as shown in Equation [19]:

$$
\begin{gathered}
W A F_{i}=1-\left(\frac{47.7 \times\left(B C S_{[1-5], i=1}-B C S_{[1-5], i}\right)}{E B W_{i=1}}\right) \\
a E B W_{i}=E B W_{i=1} \times W A F_{i}
\end{gathered}
$$

where $\mathrm{BCS}_{[1-5], i}$ is the body condition score (on a scale of 1 to 5 ). 
For both models (ERM1 and ERM2), total energy (TE; Equation [20]) is computed from TF and TP multiplied by their respective heat of combustion. For growing animals, the heat of combustion of fat has been assumed to be $9.367 \mathrm{Mcal} / \mathrm{kg}$ (Blaxter and Rook, 1953) and protein has varied from 5.554 to $5.686 \mathrm{Mcal} / \mathrm{kg}$ (Lofgreen, 1965; Garrett, 1987). For dairy cows, Andrew et al. (1994) derived values of 9.2 and $5.57 \mathrm{Mcal} / \mathrm{kg}$ for fat and protein, respectively. The NRC $(2000,2001)$ has adopted the growing animal values (9.367 and 5.554 $\mathrm{Mcal} / \mathrm{kg}$ ). Because both estimates are nearly identical, the NRC $(2000,2001)$ values are used in these models:

$$
T E_{i}=9.367 \times T F_{i}+5.554 \times T P_{i}
$$

where $\mathrm{TF}_{i}$ is the amount of body fat $(\mathrm{kg}), \mathrm{TP}_{i}$ is the amount of body protein $(\mathrm{kg}), \mathrm{TE}_{i}$ is the total energy (Mcal), and the subscript $i$ is the $i$ th period.

Assessing Changes in Body Energy. The TE of the first period, which uses the current EBW of the cow, remains unchanged; however, the TE of subsequent periods is computed with the aEBW and Equation [20]. The variation in TE is computed using Equation [21]:

$$
\Delta T E_{i}=T E_{i}-T E_{i-1} ; i \geq 2
$$

where $\Delta \mathrm{TE}_{i}$ is the change in total energy (Mcal), and subscripts $i$ and $i-1$ represent actual and previous TE values, respectively.

When the $\triangle \mathrm{TE}$ value is negative, there is a mobilization of reserve energy for milk production. The amount of milk production supported from mobilized reserves is added to the diet-allowable milk production. When the $\triangle \mathrm{TE}$ value is positive, the intake of energy is greater than the energy required for milk production. In this case, part of the available energy is used for reserve deposition rather than milk production; therefore, the amount of energy deposited has to be used to reduce the diet-allowable milk production. The variation in body protein is computed using Equation [22]:

$$
\Delta T P_{i}=T P_{i}-T P_{i-1} \quad \text { for } i \geq 2
$$

where $\Delta \mathrm{TP}_{i}$ is total protein variation $(\mathrm{kg})$, and the subscripts $i$ and $i-1$ represent actual and previous TE values, respectively.

The mobilized $(\Delta \mathrm{TE}<0$ or $\Delta \mathrm{TP}<0)$ or deposited ( $\Delta \mathrm{TE}>0$ or $\Delta \mathrm{TP}>0$ ) energy and protein are converted to milk equivalents using efficiencies of energy and protein conversion factors, as described in the next section.

Energy and Protein Efficiencies. The coefficients of energy interconversion used in our model were derived by Moe et al. (1970) using a multiple regression analysis of respiration chamber data from 126 and 224 lactating dairy cows in negative and positive energy balances, respectively. The confidence interval of the coefficients reported by Moe et al. (1970) indicated a statistical difference $(P<0.05)$ between the efficiency of $\mathrm{ME}$ to net energy of reserves $\left(\mathbf{N E}_{\mathbf{R}} ; 72.6 \%\right), \mathrm{ME}$ to $\mathrm{NE}_{\mathrm{L}}(63.5 \%)$, and $\mathrm{NE}_{\mathrm{R}}$ to $\mathrm{NE}_{\mathrm{L}}(84 \%)$, suggesting there are significant differences in the metabolism of lactating cows at a positive and negative energy balance that affect the efficienct use of energy.

When $\Delta \mathrm{TE}<0$, it indicates a negative energy balance, and energy reserves $\left(\mathrm{NE}_{\mathrm{R}}\right)$ were used for milk production. An efficiency for $\mathrm{NE}_{\mathrm{R}}$ to $\mathrm{NE}_{\mathrm{L}}$ of $82 \%$ is generally used (Moe, 1981; Fox et al., 1999; NRC, 2001). The Commonwealth Scientific and Industrial Research Organisation (1990) and the Agricultural Research Council (ARC, 1980) assume an efficiency of $84 \%$, which is supported by the study of Vermorel and Bickel (1980). Similarly, Moe et al. (1970) observed an efficiency of $84 \%$ for lactating cows in negative energy balance, which was used in these models. Analysis of the variation in the Moe et al. (1970) data indicated that the true efficiency value was between 81.7 and $86 \%$, assuming $\alpha=5 \%$ and a less rigid combination of coefficients; we used the average efficiency of $84 \%$ in our model. The milk from mobilized reserves is added to the predicted diet ME-allowable milk using Equation [23]:

$$
\begin{gathered}
\text { if } \Delta T E<0 \text { then } \Delta M i l k_{i}=\frac{-\Delta T E_{i} \times 0.84}{M k E_{i}} \\
\text { for } i \geq 2
\end{gathered}
$$

where $\Delta \mathrm{TE}$ is tissue energy variation $(\mathrm{Mcal} \mathrm{NE} / \mathrm{d}$ ), $\Delta$ Milk is milk variation $(\mathrm{kg} / \mathrm{d})$, and $\mathrm{MkE}$ is energy content of the milk (Mcal of $\mathrm{NE}_{\mathrm{L}} / \mathrm{kg}$ ).

A $\Delta \mathrm{TE}>0$ indicates a positive energy balance in which diet energy was used for reserves rather than milk production. Therefore, the first step is to convert the $\mathrm{NE}_{\mathrm{R}}$ to $\mathrm{ME}$, the second step is to convert this amount of $\mathrm{ME}$ to $\mathrm{NE}_{\mathrm{L}}$, and finally this $\mathrm{NE}_{\mathrm{L}}$ is divided by milk energy to compute the amount of milk that was not produced (Equation [24]). Commonly, an efficiency of $\mathrm{ME}$ to $\mathrm{NE}_{\mathrm{R}}$ of $75 \%$ and $\mathrm{ME}$ to $\mathrm{NE}_{\mathrm{L}}$ of $64.4 \%$ are assumed (Moe, 1981; Fox et al., 1999; NRC, 2001). Moe et al. (1970) reported that lactating cows in positive energy balance had an efficiency of $63.5 \%$ for $\mathrm{ME}$ to $\mathrm{NE}_{\mathrm{L}}$. An analysis of the possible combinations of the confidence intervals of the coefficients reported by Moe et al. (1970) suggested that the true efficiency value was between 61.2 and $65.9 \%$, assuming $\alpha=5 \%$. Moe et al. (1970) reported an efficiency of $72.6 \%$ for $\mathrm{ME}$ to $\mathrm{NE}_{\mathrm{R}}$ for lactating cows in positive energy balance; the confidence interval was 67.3 to $78.7 \%(\alpha=5 \%)$. Therefore, for $\Delta \mathrm{TE}$ $>0$ (positive energy balance), we assumed $63.5 \%$ for 
$\mathrm{ME}$ to $\mathrm{NE}_{\mathrm{L}}$ and $72.6 \%$ for $\mathrm{ME}$ to $\mathrm{NE}_{\mathrm{R}}$ (Moe et al., 1970) for our models. We then calculated the amount of milk from this amount of TE and subtracted it from the predicted diet ME-allowable milk using Equation [24]:

$$
\text { if } \begin{gathered}
\Delta T E>0 \text { then } \Delta M i l k_{i}=\frac{\Delta T E_{i} \times 0.635}{M k E_{i} \times 0.726} ; \\
i \geq 2
\end{gathered}
$$

where $\Delta \mathrm{TE}$ is tissue energy variation (Mcal of $\mathrm{NE}_{\mathrm{L}} / \mathrm{d}$ ), $\Delta$ Milk is milk variation $(\mathrm{kg} / \mathrm{d})$, and $\mathrm{MkE}$ is the energy content of the milk (Mcal of $\mathrm{NE}_{\mathrm{L}} / \mathrm{kg}$ ).

The mobilization of body tissue will also release AA that can be used directly and indirectly for milk production. The indirect form is through the recycled $\mathrm{N}$ into the gastrointestinal tract; this form is accounted for by the CNCPS model (Fox et al., 2004). The direct form, which is discussed here, is related to the incorporation of the AA produced from mobilized reserves into milk protein. In lactating sows, daily mobilization of protein was previously shown to be approximately 11 to $63 \mathrm{~g}$ and 45 to $195 \mathrm{~g}$ for first and third lactations, respectively, with an efficiency of use of 68.9 to $73.4 \%$ for milk production. These values are much greater than the values for efficiency of use of feed protein for milk production (42.7 and $46 \%$ for the first and third lactations, respectively; Lahrssen, 1988).

Dairy cows can mobilize between 7 and $13 \mathrm{~kg}$ of body protein within the first 2 to $4 \mathrm{wk}$ of lactation (Journet et al., 1983). Increasing the quantity of RUP fed prepartum had a positive effect by decreasing the loss of BW and increasing the milk protein content (Van Saun et al., 1993).

Information regarding the efficiency with which these AA are utilized for milk production in cattle is scarce. Not all mobilized AA appear in milk protein, and the AA profile of muscle does not match the milk protein profile; therefore, adequate accounting for this phenomenon is needed (McNamara, 2000). The efficiency of use of mobilized AA for milk production is likely to vary depending on the nutritional status of the animal and the $\mathrm{N}$ balance. With $\mathrm{N}$-deficient diets, the efficiency of use of $\mathrm{N}$ can be as great as $75 \%$ (NRC, 1985). Ruiz et al. (2002) indicated that using an efficiency of MP to net protein for milk production $\left(\mathbf{N P}_{\mathbf{L}}\right)$ of $75 \%$ resulted in no bias in the CNCPS-predicted MP-allowable milk. The Commonwealth Scientific and Industrial Research Organisation (1990) suggests that the mobilized net protein $\left(\mathbf{N P}_{\mathbf{R}}\right)$ has an efficiency of $80 \%$ for $\mathrm{NP}_{\mathrm{L}}$. Therefore, when $\Delta \mathrm{TP}<0$ (mobilization of body protein), we assume an efficiency of $\mathrm{NP}_{\mathrm{R}}$ to $\mathrm{NP}_{\mathrm{L}}$ of $80 \%$ and the amount of milk attributable to protein mobilization (Equation [25]) is added to the MP-allowable milk production:

$$
\text { if } \begin{gathered}
\Delta T P<0 \text { then } \Delta \text { Milk }_{i}=\frac{-\Delta T P_{i} \times 0.8}{M k T P_{i}} ; \\
i \geq 2
\end{gathered}
$$

where $\Delta \mathrm{TP}$ is tissue protein variation $(\mathrm{g} / \mathrm{d}), \mathrm{MkTP}_{i}$ is the milk true protein content $(\mathrm{g} / 100 \mathrm{~g})$, and $\Delta$ Milk is milk variation $(\mathrm{kg} / \mathrm{d})$.

This efficiency depends on the profile of the AA of the mobilized protein and on the profile of the milk protein (Newbold, 1994). Ionophores may have an impact on sparing AA from gluconeogenesis (Tedeschi et al., 2003), leading to a greater efficiency of use.

Like energy, a $\Delta \mathrm{TP}>0$ indicates a positive protein balance, in which protein was used for reserves rather than milk production. Therefore, to adjust the diet MPallowable milk, we convert $\mathrm{NP}_{\mathrm{R}}$ to $\mathrm{MP}$, which is converted to $\mathrm{NP}_{\mathrm{L}}$. There is little information on the efficiency of conversion of MP to $\mathrm{NP}_{\mathrm{R}}$ and vice versa, likely because of the difficulty in measuring it. We assume an efficiency of $70 \%$ for our model. The efficiency of MP to $\mathrm{NP}_{\mathrm{L}}$ is assumed to be $64 \%$ in the Institut National de la Recherche Agronomique (1989) system, 65\% in the beef NRC (2000) system, $67 \%$ in the dairy NRC (2001) system, and 68\% in the Agricultural and Food Research Council (AFRC, 1992) system. The 65\% efficiency was used in this model.

The amount of milk change attributable to deposition of tissue protein is computed as shown in Equation [26], which is used to adjust the diet MP-allowable milk:

$$
\text { if } \begin{gathered}
\Delta T P>0 \text { then } \Delta M i l k_{i}=\frac{\Delta T P_{i} \times 0.65}{M k T P_{i} \times 0.7} \\
i \geq 2
\end{gathered}
$$

where $\Delta \mathrm{TP}$ is tissue protein variation $(\mathrm{g} / \mathrm{d}), \mathrm{MkTP}_{i}$ is milk true protein content $(\mathrm{g} / 100 \mathrm{~g})$, and $\Delta$ Milk is milk variation $(\mathrm{kg} / \mathrm{d})$.

Adjusting Predicted ME- and MP-Allowable Milk. Figure 1 depicts a flowchart of the calculation for the 2 methods used to adjust the predicted ME- and MP-allowable milk production. In method 1 (mean), the adjusted milk production is computed for each BCS measured for the same lactating cow within a given time period, whereas method 2 (period) computes the adjusted milk production based on the first and last BCS within a given time period.

\section{Model Simulations}

A database of 134 individually fed lactating dairy cows from 3 trials was used to evaluate the adjustments for milk prediction based on first-limiting energy (ME) 


\section{Method 1 (Mean)}

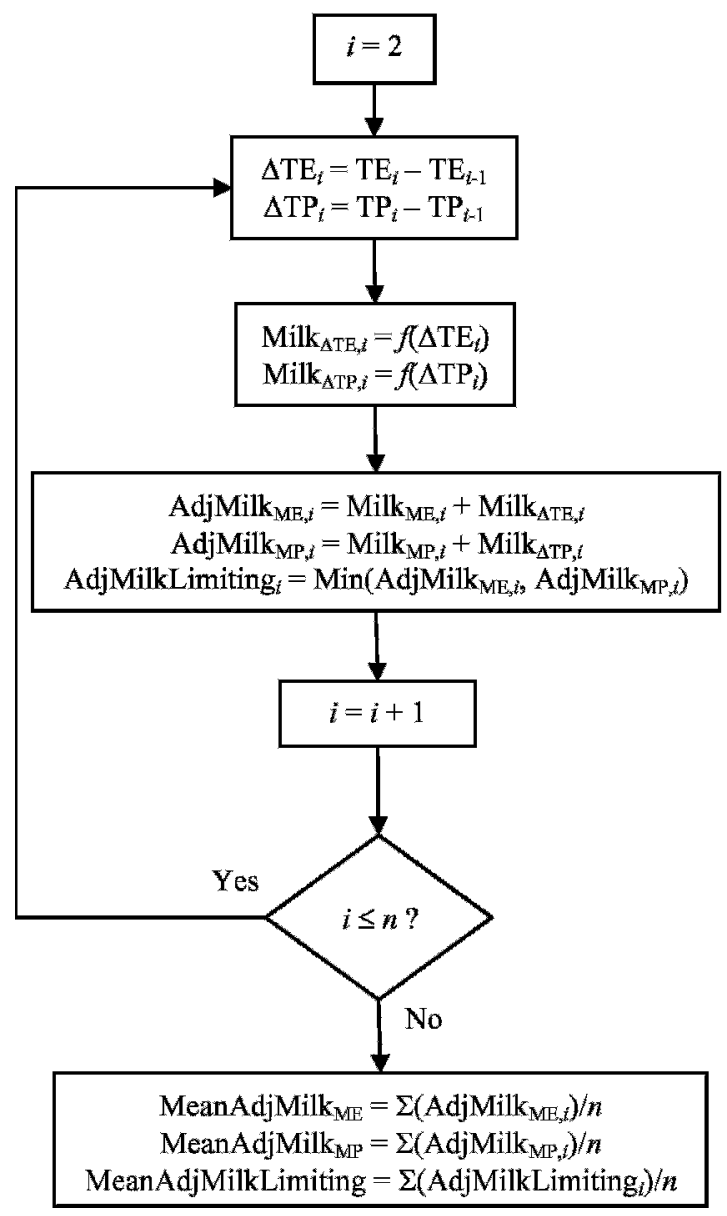

Method 2 (Period)

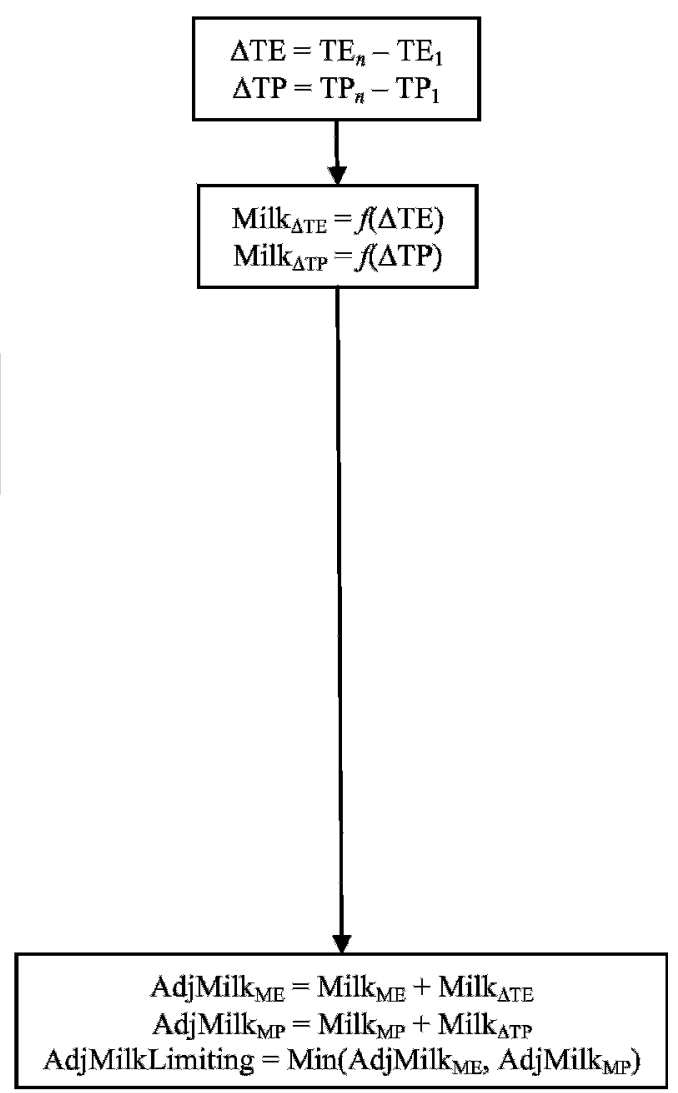

Figure 1. Flowchart of 2 methods to adjust model-predicted milk yield from ME and MP to changes in BCS. TE is total energy change (Mcal/d); TP is total protein change $(\mathrm{g} / \mathrm{d})$; and $\mathrm{Milk}_{\Delta \mathrm{TE}}$ and $\mathrm{Milk}_{\Delta \mathrm{TP}}$ are the variations in model-predicted milk attributable to changes in $\mathrm{BCS}(\mathrm{kg} / \mathrm{d})$, and are functions of efficiency of use of energy and protein.

or protein (MP). All diets were balanced to meet NRC (2001) recommendations for minerals and vitamins. Trial 1 had 15 multiparous Holstein cows averaging $126 \mathrm{DIM}$ and $560 \mathrm{~kg}$ of BW that were fed fresh-cut orchardgrass (Dactylus glomerata L.) and a concentrate mix with or without monensin for 3 wk (Ruiz et al., 2001). Trial 2 consisted of 22 multiparous and 16 firstlactation Holstein cows averaging 263 DIM and $614 \mathrm{~kg}$ of BW, receiving 3 levels of CP (low, medium, and high) in the TMR for 4 wk (Ruiz et al., 2002). Trial 3 comprised 60 multiparous and 21 primiparous Holstein cows (Stone, 1996). Animals from trial 3 were fed 3 treatments to evaluate soyhulls as forage or concentrate replacement for $14 \mathrm{wk}$. In general, energy was first limiting in trial 3, whereas protein was first limiting in trials 1 and 2 . The database contained adequate information on feed characteristics, animal description and performance, and environment to predict daily milk production using the NRC (2001) and CNCPS (Fox et al., 2004) models. All predictions were made for each cow weekly. The BCS measurements were taken by the same person within each trial.

\section{Evaluation of the Model Predictions}

Assessment of the adequacy of mathematical models is only possible through the use of a combination of several statistical and empirical analyses and proper investigation regarding the purposes of the model initially conceptualized (Tedeschi, 2006). Therefore, several techniques were used to evaluate and compare the models in this study. Briefly, linear regression analysis 
observed on model-predicted values was conducted to identify precision and accuracy in the prediction of the rate of milk production. The coefficient of determination $\left(\mathrm{r}^{2}\right.$; Neter et al., 1996), confidence intervals for the parameters (Mitchell, 1997), and a simultaneous test for the intercept and slope (Dent and Blackie, 1979; Mayer et al., 1994) were used. The deviation plot (model-predicted minus observed values against observed values) were used to study the behavior of model prediction compared with observed values (Mitchell and Sheehy, 1997). All residual analysis for outliers (extreme and influential points), homoscedasticity, and normal distribution assumptions were performed on the residual (regression-predicted minus observed values) against regression-predicted values (Neter et al., 1996).

Additional techniques were also used, as discussed by Tedeschi (2006), including accuracy from the concordance correlation coefficient (CCC by Lin, $1989 ; C_{b}$ by Nickerson, 1997; and $A_{\rho}$ by Liao, 2003), mean bias (Cochran and Cox, 1957), and mean square error of prediction (MSEP; Bibby and Toutenburg, 1977). The MSEP values were expanded into 3 fractions to represent errors in central tendency, errors attributable to regression, and errors attributable to disturbances (or random errors), that is, unexplained variance that could not be accounted for by the linear regression (Theil, 1961). Equation [27] has the equation modified by Tedeschi (2006):

$$
\begin{aligned}
M S E P= & (\bar{X}-\bar{Y})^{2}+s_{X}^{2} \times(1-b)^{2} \\
& +\left(1-r^{2}\right) \times s_{Y}^{2}
\end{aligned}
$$

where MSEP is the mean square error of prediction, $X_{i}$ is the $i$ th model-predicted value, $Y_{i}$ is the $i$ th observed value, $s^{2}$ is the variance associated with observed and model-predicted values, and $r^{2}$ is the coefficient of determination.

The 3 terms in Equation [27] represent errors in central tendency (mean bias), errors attributable to regression (systematic or slope bias), and errors attributable to disturbances (or random errors), that is, unexplained variance that cannot be accounted for by the linear regression. Each error term is commonly evaluated as a proportion of the total MSEP, thus indicating which terms have a greater influence in the MSEP. Detailed information about all these assessment techniques and the software used to perform the model comparison analyses are discussed in Tedeschi (2006).

The MSEP was used to compare the model accuracy among different combinations of nutritional models (CNCPS vs. NRC), reserves models (ERM1 vs. ERM2), and methods of calculation (mean vs. period) compared with observed values. Equation [28] was used to com-

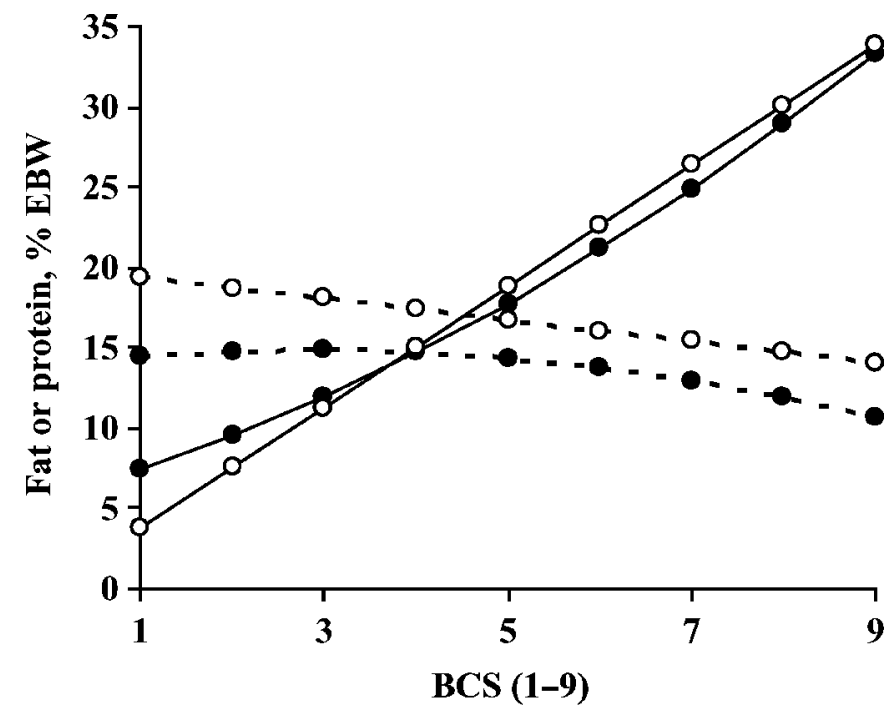

Figure 2. Prediction of the content of body fat (solid lines) and protein (dotted lines) in the empty BW (EBW) as a function of the BCS, using the empirical reserves model based on NRC (2001; open circles) and a new model (solid circles).

pute the difference between MSEP ( $\triangle$ MSEP) of any 2 sets of model predictions for each data point, and Equation [29] was used to compute the mean and variance of the $\triangle \mathrm{MSEP}$. A $t$-test was conducted to statistically verify the difference of $\triangle$ MSEP from zero. In a practical application, if the standard deviation of $\triangle \mathrm{MSEP}$ were greater than the $\triangle \mathrm{MSEP}$ value, it would indicate that the $\triangle \mathrm{MSEP}$ was not different from zero:

$$
\begin{gathered}
\triangle M S E P_{i}=\left(Y_{i}-f(X)_{i}\right)^{2}-\left(Y_{i}-g(X)_{i}\right)^{2} \\
\overline{\Delta M S E P}=\frac{1}{n} \sum_{i=1}^{n}\left[\Delta M S E P_{i}\right] \\
\sigma_{\Delta M S E P}^{2}=\frac{1}{n-1} \sum_{i=1}^{n}\left[\Delta M S E P_{i}-\overline{\Delta M S E P}\right]^{2}
\end{gathered}
$$

where $\triangle \mathrm{MSEP}$ is the difference between the 2 sets of model predictions for each data point, $f(X)_{i}$ are modelpredicted values using one set of predicted values and $g(X)_{i}$ are the model-predicted values using another set of predicted values, $Y$ is the observed milk production, $\overline{\triangle M S E P}$ is the mean of $\triangle \mathrm{MSEP}$, and $\sigma_{\triangle M S E P}^{2}$ is the variance of $\triangle \mathrm{MSEP}$.

A meta-analysis was conducted according to Equation [30] (Littell et al., 1999) and indicated no random influence of the trials on the intercept $(P=0.20)$ and slope $(P=0.36)$; therefore, the trials were pooled in the analysis: 
Table 1. Calculation of body reserves for an actual cow to demonstrate adjustment of predicted milk production on a weekly or initial and final calculation basis ${ }^{1}$

\begin{tabular}{|c|c|c|c|c|c|c|c|c|c|c|c|c|c|}
\hline BW & BCS & $\mathrm{Mk}$ & Fat & Prot & $\mathrm{ME}$ & MP & $\mathrm{TF}$ & $\mathrm{TP}$ & $\mathrm{TE}$ & $\Delta \mathrm{TE}$ & $\Delta \mathrm{TP}$ & $\mathrm{ME}_{\text {adj }}$ & $\mathrm{MP}_{\text {adj }}$ \\
\hline & \multicolumn{13}{|c|}{ (Weekly calculation basis) } \\
\hline 676 & 4.4 & 44.7 & 4.3 & 3.1 & 28.3 & 32.1 & 162.3 & 82.2 & 1,977 & 0 & 0 & 28.3 & 32.1 \\
\hline 669 & 4.1 & 51.4 & 3.6 & 2.6 & 35.5 & 42.9 & 144.7 & 81.5 & 1,808 & -169 & -0.70 & 65.7 & 46.0 \\
\hline 640 & 4.0 & 53.6 & 3.4 & 2.5 & 39.9 & 48.2 & 139.0 & 81.2 & 1,753 & -55 & -0.27 & 50.1 & 49.4 \\
\hline 640 & 3.7 & 56.3 & 3.1 & 2.3 & 45.4 & 56.5 & 122.5 & 80.3 & 1,593 & -160 & -0.90 & 76.8 & 61.0 \\
\hline 626 & 3.3 & 52.7 & 3.2 & 2.4 & 38.7 & 47.3 & 101.8 & 78.9 & 1,392 & -202 & -1.44 & 77.5 & 54.2 \\
\hline 643 & 3.2 & 50.6 & 3.2 & 2.5 & 41.1 & 48.1 & 96.9 & 78.5 & 1,343 & -48 & -0.40 & 50.3 & 50.0 \\
\hline 619 & 3.0 & 49.9 & 3.1 & 2.5 & 45.1 & 51.6 & 87.3 & 77.6 & 1,249 & -94 & -0.86 & 63.4 & 55.5 \\
\hline 626 & 3.3 & 50.3 & 2.9 & 2.4 & 48.8 & 56.7 & 101.8 & 78.9 & 1,392 & 143 & 1.26 & 18.9 & 49.7 \\
\hline 604 & 3.2 & 46.5 & 3.1 & 2.5 & 46.7 & 53.6 & 96.9 & 78.5 & 1,343 & -48 & -0.40 & 56.0 & 55.4 \\
\hline 624 & 3.0 & 47.3 & 2.9 & 2.4 & 45.4 & 52.9 & 87.3 & 77.6 & 1,249 & -94 & -0.86 & 64.4 & 57.0 \\
\hline 613 & 3.0 & 42.4 & 3.1 & 2.7 & 46.3 & 49.3 & 87.3 & 77.6 & 1,249 & 0 & 0.00 & 46.3 & 49.3 \\
\hline 617 & 3.1 & 45.2 & 2.7 & 2.4 & 49.7 & 56.2 & 92.0 & 78.1 & 1,296 & 47 & 0.44 & 39.5 & 53.8 \\
\hline 609 & 3.0 & 39.6 & 3.0 & 2.7 & 47.0 & 49.6 & 87.3 & 77.6 & 1,249 & -47 & -0.44 & 56.1 & 51.4 \\
\hline \multirow[t]{2}{*}{602} & 3.0 & 41.1 & 2.7 & 2.6 & 50.5 & 52.8 & 87.3 & 77.6 & 1,249 & 0 & 0 & 50.5 & 52.8 \\
\hline & \multicolumn{13}{|c|}{ (Initial and final calculation basis) } \\
\hline 676 & 4.4 & 44.7 & 4.3 & 3.1 & 28.3 & 32.1 & 162.3 & 82.2 & 1,977 & 0 & 0 & 28.3 & 32.1 \\
\hline 602 & 3.0 & 41.1 & 2.7 & 2.6 & 50.5 & 52.8 & 87.3 & 77.6 & 1,249 & -728 & -4.56 & 53.4 & 51.3 \\
\hline
\end{tabular}

${ }^{1}$ Calculations were performed for cow \#4675 from trial 3. BCS is body condition score (on a scale of 1 to 5); Mk is observed milk (kg/d); Fat is milk fat (\%); Prot is milk true protein (\%); ME is ME-allowable milk production $(\mathrm{kg} / \mathrm{d})$; MP is MP-allowable milk production $(\mathrm{kg} / \mathrm{d})$; TF is amount of body fat $(\mathrm{kg})$; TP is amount of body protein (kg); TE is energy from body fat and protein (Mcal); $\Delta \mathrm{TE}$ is variation in energy content of the body attributable to changes in BCS (Mcal); $\triangle \mathrm{TP}$ is variation in protein content of the body attributable to changes in $\mathrm{BCS}(\mathrm{kg}) ; \mathrm{ME}_{\text {adj }}$ is $\mathrm{ME}$-allowable milk adjusted for changes in body energy content $(\mathrm{kg} / \mathrm{d})$; and $\mathrm{MP}_{\mathrm{adj}}$ is MP-allowable milk adjusted for changes in body protein content (kg/d).

$$
\begin{gathered}
Y_{i j}=a_{i}+b_{i} X_{i j}+e_{i j} \\
\left(\begin{array}{l}
a_{i} \\
b_{i}
\end{array}\right) \sim i i d N\left[\left(\begin{array}{l}
\alpha \\
\beta
\end{array}\right), \Omega\right] \\
\Omega=\left(\begin{array}{cc}
\sigma_{a}^{2} & \sigma_{a b} \\
\sigma_{a b} & \sigma_{b}^{2}
\end{array}\right)
\end{gathered}
$$

where $Y_{i j}$ is the observed milk production $(\mathrm{kg} / \mathrm{d}) ; X_{i j}$ is the model-predicted milk production $(\mathrm{kg} / \mathrm{d}) ; e_{i j}$ is the random error, independently, identically, and normally distributed with mean zero and variance $\sigma^{2}$; and $a$ and $b$ are fixed variables, with variance-covariance represented by $\Omega$. A variance component structure was used in this analysis based on the -2 REML log likelihood values.

\section{RESULTS AND DISCUSSION}

Figure 2 depicts the comparison of ERM1 and ERM2 to predict empty body TF and TP from BCS (Equations [6] to [7] and [16] to [17], respectively). The prediction of TF was very similar between ERM1 and ERM2. However, the prediction of TP was consistently greater for ERM1, which is implemented in the NRC (2000, 2001) models.

Table 1 demonstrates the sequence of calculation of ME- and MP-allowable milk adjusted for changes in

\begin{tabular}{|c|c|c|c|c|c|c|c|c|c|c|}
\hline BCS & \multicolumn{5}{|c|}{ SBW for ERM1 } & \multicolumn{5}{|c|}{ SBW for ERM2 } \\
\hline 1 to 2 & $154(2.8)$ & $164(2.9)$ & $173(3.1)$ & $182(3.2)$ & $191(3.4)$ & $164(4.3)$ & $184(4.3)$ & $205(4.3)$ & $225(4.3)$ & $245(4.3)$ \\
\hline 3 to 4 & $190(3.4)$ & $200(3.6)$ & $211(3.8)$ & $222(4.0)$ & $232(4.1)$ & $172(5.4)$ & $193(5.4)$ & $215(5.4)$ & $236(5.4)$ & $258(5.4)$ \\
\hline 4 to 5 & 209 (3.7) & $220(3.9)$ & $231(4.1)$ & $243(4.3)$ & $254(4.5)$ & $175(5.9)$ & $197(5.9)$ & $219(5.9)$ & $241(5.9)$ & $262(5.9)$ \\
\hline 5 to 6 & $228(4.1)$ & $240(4.3)$ & $253(4.5)$ & $265(4.7)$ & 277 (4.9) & $178(6.5)$ & $200(6.5)$ & $222(6.5)$ & $244(6.5)$ & 267 (6.5) \\
\hline 6 to 7 & 249 (4.4) & $262(4.7)$ & 275 (4.9) & $288(5.1)$ & $301(5.4)$ & $180(7.0)$ & $203(7.0)$ & $225(7.0)$ & $248(7.0)$ & $270(7.0)$ \\
\hline
\end{tabular}

Table 2. Energy reserves (Mcal) for cows with different shrunk BW (SBW, kg) and BCS for 2 empirical reserves models (ERM1 and ERM2, respectively) ${ }^{1}$

${ }^{1}$ Within parentheses are megacalories per kilogram of SBW change. The ERM1 assumes a variable value for change in BW per change in BCS, whereas the ERM2 assumes a fixed value of $56 \mathrm{~kg}$ of SBW (see text). 
A
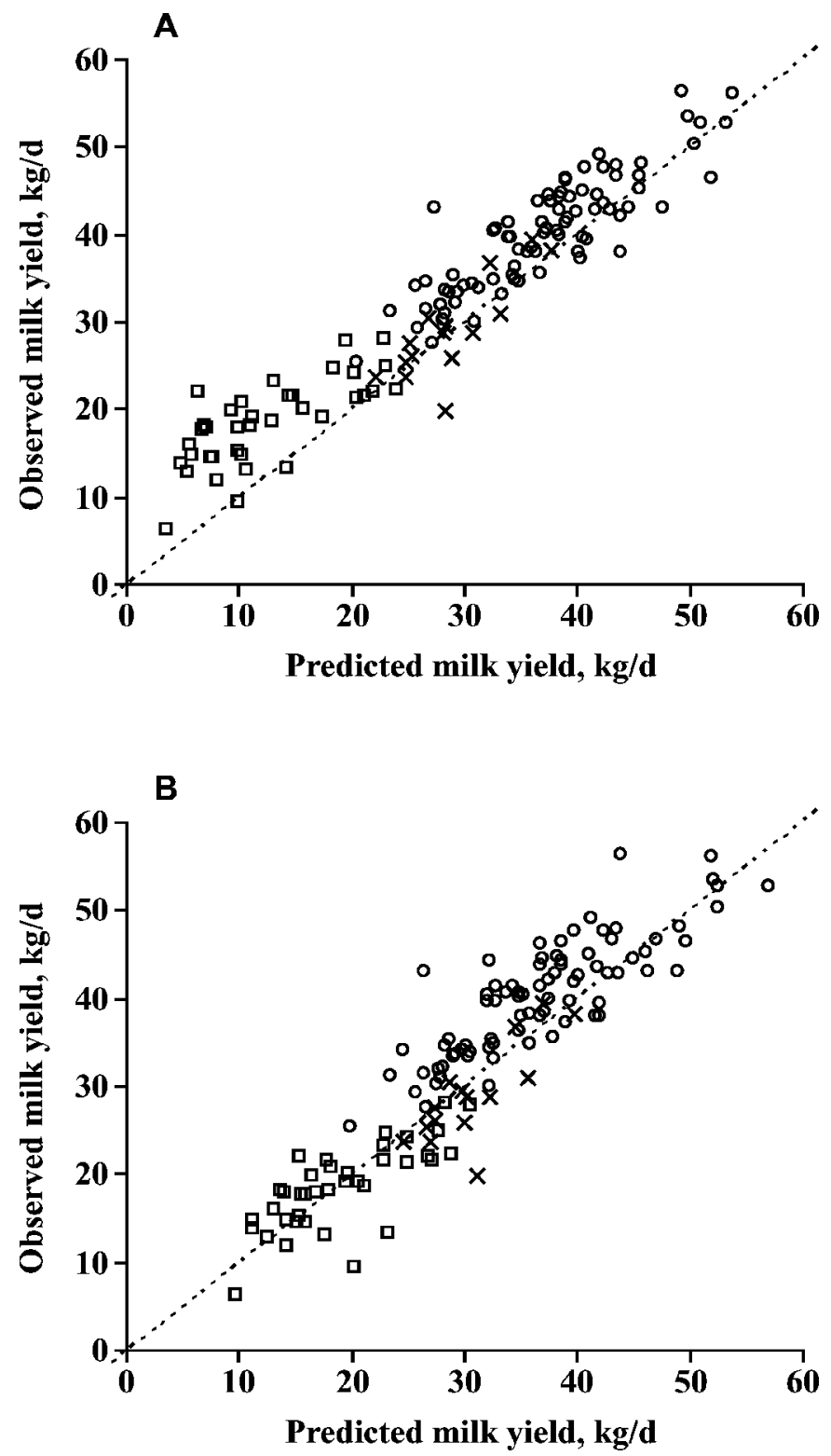

Figure 3. Comparison between observed milk $(\mathrm{kg} / \mathrm{d})$ and firstlimiting ME- or MP-allowable milk using (A) the NRC (2001) and (B) the Cornell Net Carbohydrate and Protein System (Fox et al., 2004) models without BCS adjustment. Symbols designate different trials (Stone, 1996, $\mathrm{n}=81$, $\bigcirc$; Ruiz et al., 2001, $\mathrm{n}=15, \times$; Ruiz et al., 2002, $\mathrm{n}=38, \square)$.

BCS, using a cow from trial 3 that averaged $50 \mathrm{~kg} / \mathrm{d}$ of milk. The mean of first-limiting diet ME- or MPallowable milk as predicted by the CNCPS (Fox et al., 2004) using ERM1 was $43.5 \mathrm{~kg} / \mathrm{d}$ (Table 1), indicating that the model was underpredicting milk production by $6.5 \mathrm{~kg} / \mathrm{d}$. When the adjustment for BCS change was performed, the mean first-limiting ME- or MP-allowable milk was $47.4 \mathrm{~kg} / \mathrm{d}$ for the method 1 calculation (mean across all measurements) and $51.3 \mathrm{~kg} / \mathrm{d}$ for the method 2 calculation (first and last measurements; Table 1). This suggests that adjusting for the first and last BCS values (method 2) was more accurate than using the mean of the adjusted ME- or MP-allowable milk values for all BCS changes (method 1), likely because the BCS changes between weeks were highly variable.

The mobilization of protein and its use for milk protein production may explain part of the variation associated with prediction of the dynamics of fat reserves by mathematical models (McNamara, 2000). Unlike fat mobilization, protein mobilization as a proportion of BW change seems to be less variable (Figure 2). The Agricultural and Food Research Council (AFRC, 1992) suggests a fixed contribution of $13.8 \%$ of BW change for protein, which is very similar to the values predicted in Figure 2. Metabolizable protein was predicted by both models (NRC and CNCPS) to be the first-limiting factor driving milk production for trials 1 and 2 (Ruiz et al., 2001, 2002), whereas ME was the first-limiting factor for trial 3 (Stone, 1996). Therefore, the MP adjustment (Equations [25] and [26]) was more important in trials 1 and 2 than in trial 3. The Commonwealth Scientific and Industrial Research Organisation (1990) indicates that the mobilized protein could be used in the rumen rather than for milk production (indirect effect).

Table 2 lists the energy content of repletion and depletion of body reserves for changes in the BCS of cows for 5 different SBW. These calculations were made with Equations [6] to [9] for ERM1, Equations [16] to [19] for ERM2, and Equation [20] for both models. The energy content per change in kilogram of SBW $(\Delta \mathbf{S B W})$ varied from 4.3 to $8.1 \mathrm{Mcal} / \Delta \mathrm{SBW}$ for ERM2 and 2.8 to $6.3 \mathrm{Mcal} / \Delta \mathrm{SBW}$ for ERM1. These values are in agreement with several studies (Houghton et al., 1990; Buskirk et al., 1992). Buskirk et al. (1992) reported values ranging from 2.8 to $7.8 \mathrm{Mcal} / \Delta \mathrm{SBW}$. However, for ERM2, within a BCS the megacalories per $\triangle \mathrm{SBW}$ did not change with SBW, whereas for ERM1 this value changed with SBW. The mean of ERM1 is greater than the value of $3.6 \mathrm{Mcal} / \Delta \mathrm{SBW}$ reported by SchwagerSuter et al. (2001b).

The values for energy content of repletion and depletion of body reserves were lower in ERM1 compared with ERM2 for a given BW and BCS status (Table 2). This difference was expected because ERM2 assumes a fixed value of $56 \mathrm{~kg}$ of SBW (47.7 kg of EBW) regardless of the BCS of the animal (Equations [18] and [19]), whereas ERM1 assumes a variable value, depending on the BCS of the animal (Equations [8] and [9]). The values for megacalories per $\triangle \mathrm{SBW}$ obtained for ERM1 (Table 2) were identical to those reported by Fox et al. (1999), but the values for energy of repletion and 
Table 3. Evaluation of 2 submodels [empirical reserves model 1 (ERM1) and 2 (ERM2)] ${ }^{1}$ and 2 methods (mean or period) for adjusting MEand MP-allowable milk production ${ }^{2}$

\begin{tabular}{|c|c|c|c|c|c|c|c|c|c|c|}
\hline \multirow[b]{3}{*}{ Item } & \multicolumn{5}{|c|}{ NRC-predicted milk production } & \multicolumn{5}{|c|}{ CNCPS-predicted milk production } \\
\hline & \multirow[b]{2}{*}{ Original } & \multicolumn{2}{|c|}{ ERM1 } & \multicolumn{2}{|c|}{ ERM2 } & \multirow[b]{2}{*}{ Original } & \multicolumn{2}{|c|}{ ERM1 } & \multicolumn{2}{|c|}{ ERM2 } \\
\hline & & Mean & Period & Mean & Period & & Mean & Period & Mean & Period \\
\hline \multicolumn{11}{|l|}{ Linear regression analysis } \\
\hline $\mathrm{r}^{2}$ & 0.90 & 0.90 & 0.92 & 0.89 & 0.92 & 0.85 & 0.83 & 0.89 & 0.82 & 0.89 \\
\hline$\sqrt{M S E}$ & 3.59 & 3.71 & 3.31 & 3.79 & 3.30 & 4.50 & 4.76 & 3.84 & 4.87 & 3.87 \\
\hline$P$-value $\left(\beta_{0}=0, \beta_{1}=1\right)$ & $<0.01$ & $<0.01$ & $<0.01$ & $<0.01$ & $<0.01$ & $<0.01$ & $<0.01$ & 0.32 & $<0.01$ & 0.53 \\
\hline \multicolumn{11}{|c|}{ Concordance correlation analysis } \\
\hline$C_{b}$ & 0.95 & 0.95 & 0.97 & 0.95 & 0.97 & 0.98 & 0.97 & 1.00 & 0.97 & 1.00 \\
\hline$A_{\rho}$ & 0.95 & 0.95 & 0.96 & 0.94 & 0.96 & 0.98 & 0.97 & 1.00 & 0.97 & 1.00 \\
\hline Mean bias, $\%$ & 12.3 & 12.7 & 6.21 & 13.1 & 7.13 & 5.34 & 7.34 & -0.45 & 7.54 & 0.42 \\
\hline \multicolumn{11}{|l|}{ Mean square error of } \\
\hline prediction (MSEP) $\sqrt{M S E P}$ & 5.42 & 5.61 & 4.69 & 5.71 & 4.72 & 4.77 & 5.23 & 3.85 & 5.35 & 3.86 \\
\hline Mean bias, $\%$ & 44.0 & 43.2 & 16.8 & 44.6 & 21.4 & 12.2 & 18.6 & 0.15 & 18.5 & 0.13 \\
\hline Systematic bias, \% & 12.8 & 13.8 & 34.1 & 12.1 & 30.3 & 0.14 & 0 & 1.58 & 0 & 0.83 \\
\hline Random errors, $\%$ & 43.2 & 43.0 & 49.1 & 43.3 & 48.2 & 87.7 & 81.5 & 98.3 & 81.5 & 99.0 \\
\hline
\end{tabular}

${ }^{1}$ See text for more information on the ERM1 and ERM2 submodels.

${ }^{2}$ Mean uses the mean of weekly BCS values, and Period uses the first and last BCS values to adjust ME- and MP-allowable milk. National Research Council (NRC)-predicted milk production is from NRC (2001), whereas Cornell Net Carbohydrate and Protein System (CNCPS)predicted milk production is from Fox et al. (2004). MSE = mean square error; $\beta_{0}=$ intercept of the linear regression; $\beta_{1}=$ slope of the linear regression. $C_{b}=$ Accuracy (Lin, 1989); $A_{\rho}=$ concordance correlation coefficient (Liao, 2003).

depletion per unit of BCS change were different from those developed by Fox et al. (1999) and the NRC (2000).

Figure 3 depicts the relationship between observed milk yield and milk yield predicted by the NRC (2001) and CNCPS (Fox et al., 2004) models without adjustment for changes in BCS. The NRC (2001) model had greater precision (based on the coefficient of determination of the regression between observed and model-predicted values) than the CNCPS model $(0.90$ vs. 0.85 , respectively; Table 3) but had a greater mean bias (12.3 vs. $5.34 \%$, respectively; Table 3 ). The root of MSEP values of the unadjusted (original) predictions by the CNCPS and NRC models differed (4.77 vs. 5.42, respectively; $P=0.03$ ). Within the CNCPS and NRC predictions, the mean method for both ERM1 and ERM2 had similar MSEP $(P>0.20)$ and were lower $(P<0.01)$ than the unadjusted (original) and the period method MSEP values (Table 3). Analysis of the MSEP decomposition indicated that the mean and systematic biases in the NRC (2001) predictions were a greater source of disparity than in the CNCPS prediction and that the random errors were greater in the CNCPS than in the NRC (2001) predictions. These findings suggest that the NRC (2001) predictions tended to be more homogeneous (precise) than those from the CNCPS model but were less accurate, as also indicated by the concordance correlation coefficient analysis (Table 3 ). We concluded that both models adequately predicted the first-limiting MEor MP-allowable milk.
Table 3 also shows the outcome of the comparison between ERM1 and ERM2, and methods 1 (mean of the adjustments) and 2 (first and last measurement to adjust milk production to BCS changes) of calculation for both systems (NRC and CNCPS). The adjustment of first-limiting ME- or MP-allowable milk for BCS changes improved the precision and accuracy of both systems, as shown in Table 3. In general, method 2 was more appropriate than method 1 for both ERM1 and ERM2, suggesting that adjusting milk production for weekly variations of BCS added more variability to a measurement (BCS) that is already highly subjective. In agreement with our findings, McNamara (2000) concluded that the use of BCS is quite helpful when applied over a long period of time ( $>1 \mathrm{mo}$ ). The amount of BW or fat change per unit of BCS is highly variable (25 to $50 \mathrm{~kg} / \triangle \mathrm{BCS}$; Garnsworthy, 1988; Komaragiri and Erdman, 1997) and depends on several factors (e.g., age, breed, plane of nutrition, parity, etc.). This might explain why a simple adjustment (method 2 of calculation) can be more accurate than sequential adjustments (method 1 of calculation).

Figure 4 shows the relationship of observed milk production and first-limiting ME- or MP-allowable milk adjusted for changes in BCS. In agreement with Table 3 , the adjustment shifted the prediction to the right, decreasing the overall underprediction of both models. However, the improvements in model precision and accuracy were small. 


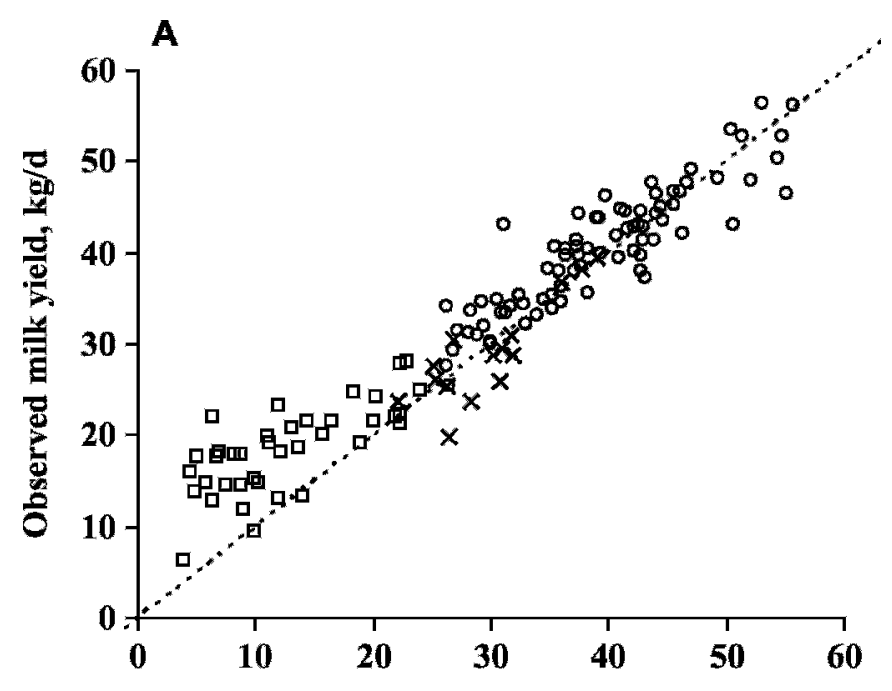

Predicted milk yield adjusted for BCS changes, $\mathrm{kg} / \mathrm{d}$

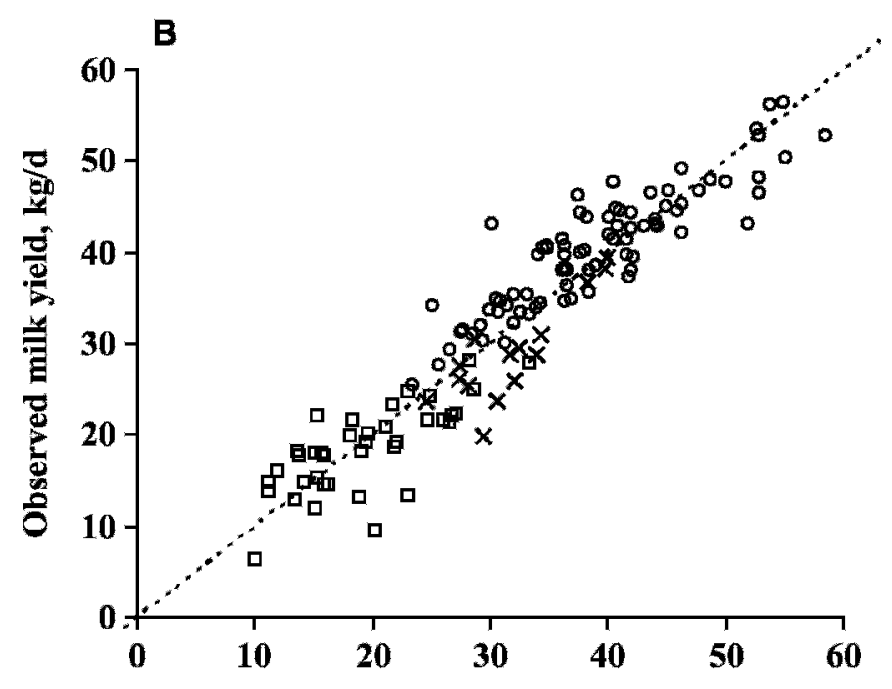

Predicted milk yield adjusted for BCS changes, $\mathrm{kg} / \mathrm{d}$

Figure 4. Comparison between observed milk (kg/d) and firstlimiting ME- or MP-allowable milk using (A) the NRC (2001) and (B) the Cornell Net Carbohydrate and Protein System (Fox et al., 2004) models with BCS adjustment with first and last BCS measurements (method 2) based on equations from Otto et al. (1991; model 2). Symbols designate different trials (Stone, 1996, $\mathrm{n}=81$, $\bigcirc$; Ruiz et al., 2001, $\mathrm{n}=15, \times$; and Ruiz et al., 2002, $\mathrm{n}=38, \square)$.

Despite the good agreement between ERM1 and ERM2, the adjustments proposed by ERM2 do not account for differences between mature small- and largesized lactating cows. Changes in BW per unit of BCS change have been shown to be highly variable ( 25 to 50 $\mathrm{kg} / \triangle \mathrm{BCS}$ ) across BCS categories (Garnsworthy, 1988; Komaragiri and Erdman, 1997). We expect that ERM1 is a more robust model than ERM2 for situations in which the animals are different from the ones used in the study by Otto et al. (1991).

Schwager-Suter et al. (2001a) found that changes in BW were a better indicator of body tissue change than changes in BCS. The ERM2 can be implemented with a variable change in $\mathrm{BW}$ rather than a fixed value of $47.7 \mathrm{~kg}$ of EBW, as reported by Tennant et al. (2002). However, as we have stated, variation in BW is difficult to assess at the farm level because of changes in gut fill. As our model evaluation indicated, BCS can be used to account for energy mobilization and repletion.

In our model, we assumed fixed values for the fat and protein content of mobilized and replenished tissue. Williams et al. (1989) suggested that the contribution of energy from fat and protein (Equation [20]) be adjusted by stage of lactation. The authors proposed multiplicative factors for fat and protein (1.4 and 0.6, respectively) to account for differences in the amount of fat and protein mobilized during early lactation, as opposed to the composition of gain during late lactation.

More complex models of adipose tissue biochemistry have been discussed by McNamara (2000) and Baldwin (1995, chapters 12 and 16). These models use substrate saturation and enzyme kinetics or mass action to modulate the mechanisms of lipogenesis and lipolysis biochemically. Simpler models that work within the NRC and CNCPS frameworks are needed to account for BCS changes of lactating cows and predict production responses with different feeding systems given an animal's potential performance, energy and protein supply, environmental conditions, and body reserve management strategies. Our results indicate that the model presented can be used to account for changes in BCS in formulating diets on farms and in evaluating differences in milk production with different experimental diets.

\section{REFERENCES}

AFRC (Agricultural and Food Research Council). 1992. Nutritive requirements of ruminant animals: Protein (Report 9). Nutr. Abstr. Rev. 62:787-835.

Andrew, S. M., D. R. Waldo, and R. A. Erdman. 1994. Direct analysis of body composition of dairy cows at three physiological stages. J. Dairy Sci. 77:3022-3033.

ARC (Agricultural Research Council). 1980. The Nutrient Requirements of Ruminant Livestock. ARC/The Gresham Press, London, UK.

Baldwin, R. L. 1995. Modeling Ruminant Digestion and Metabolism. Chapman \& Hall, New York, NY.

Baldwin, R. L., J. France, D. E. Beever, M. Gill, and J. H. M. Thornley. 1987a. Metabolism of the lactating cow. III. Properties of mechanistic models suitable for evaluation of energetic relationships and factors involved in the partition of nutrients. J. Dairy Res. 54:133-145.

Baldwin, R. L., J. France, and M. Gill. 1987b. Metabolism of the lactating cow. I. Animal elements of a mechanistic model. J. Dairy Res. 54:77-105. 
Baldwin, R. L., J. H. M. Thornley, and D. E. Beever. 1987c. Metabolism of the lactating cow. II. Digestive elements of a mechanistic model. J. Dairy Res. 54:107-131.

Bibby, J., and H. Toutenburg. 1977. Prediction and improved estimation in linear models. John Wiley \& Sons, Berlin, Germany.

Blaxter, K. L., and J. A. F. Rook. 1953. The heat of combustion of the tissues of cattle in relation to their chemical composition. Br. J. Nutr. 7:83-91.

Buskirk, D. D., R. P. Lemenager, and L. A. Horstman. 1992. Estimation of net energy requirements $\left(\mathrm{NE}_{\mathrm{m}}\right.$ and $\left.\mathrm{NE}_{\Delta}\right)$ of lactating beef cows. J. Anim. Sci. 70:3867-3876.

Cantrell, J. A., J. R. Kropp, S. L. Armbruster, K. S. Lusby, R. P. Wettemann, and R. L. Hintz. 1981. The influence of postpartum nutrition and weaning age of calves on cow body condition, estrus, conception rate and calf performance of fall-calving beef cows. No. MP-112. Oklahoma Agricultural Experimental Station, Stillwater, OK.

Cerosaletti, P. E., D. G. Fox, and L. E. Chase. 2004. Phosphorus reduction through precision feeding of dairy cattle. J. Dairy Sci. 87:2314-2323.

Chilliard, Y., M. Cisse, R. LeFaivre, and B. Remond. 1991. Body composition of dairy cows according to lactation stage, somatotropin treatment, and concentrate supplementation. J. Dairy Sci. 74:3103-3116.

Cochran, W. G., and G. M. Cox. 1957. Experimental Design. John Wiley \& Sons, New York, NY.

CSIRO (Commonwealth Scientific and Industrial Research Organisation). 1990. Feeding Standards for Australian Livestock: Ruminants. CSIRO, Melbourne, Australia.

Dent, J. B., and M. J. Blackie. 1979. Systems Simulation in Agriculture. Applied Science, London, UK.

Fox, D. G., L. O. Tedeschi, T. P. Tylutki, J. B. Russell, M. E. Van Amburgh, L. E. Chase, A. N. Pell, and T. R. Overton. 2004. The Cornell Net Carbohydrate and Protein System model for evaluating herd nutrition and nutrient excretion. Anim. Feed Sci. Technol. 112:29-78.

Fox, D. G., M. E. Van Amburgh, and T. P. Tylutki. 1999. Predicting requirements for growth, maturity, and body reserves in dairy cattle. J. Dairy Sci. 82:1968-1977.

Garnsworthy, P. C. 1988. The effect of energy reserves at calving on performance of dairy cows. Pages 151-170 in Nutrition and Lactation in the Dairy Cow. P. C. Garnsworthy, ed. Butterworths, London, UK.

Garrett, R. P., and H. Hinman. 1969. Re-evaluation of the relationship between carcass density and body composition of beef steers. J. Anim. Sci. 28:1-5.

Garrett, W. N. 1987. Relationship between energy metabolism and the amounts of protein and fat deposited in growing cattle. Pages 98-101 in Proc. Energy Metabolism, 10. Rowman \& Littlefield, Lanham, MD.

Gibb, M. J., W. E. Irvings, M. S. Dhanoa, and J. D. Sutton. 1992. Changes in body composition of autumn-calving Holstein Friesian cows over the first 29 weeks of lactation. Anim. Prod. 55:339-360.

Hankins, O. G., and P. E. Howe. 1946. Estimation of the composition of beef carcasses and cuts. Technical Bulletin No. 926. USDA, Washington, DC.

Herd, D. B., and L. R. Sprott. 1986. Body condition, nutrition, and reproduction of beef cows. No. B-1526. Texas A\&M University Agricultural Extension, College Station, TX.

Houghton, P. L., R. P. Lemenager, G. E. Moss, and K. S. Hendrix. 1990. Prediction of postpartum beef cow body composition using weight to height ratio and visual body condition score. J. Anim. Sci. 68:1428-1437.

INRA (Institut National de la Recherche Agronomique). 1989. Ruminant Nutrition. Recommended Allowances and Feed Tables. INRA/John Libbey Eurotext, Montrouge, France.

Journet, M., C. Champredon, R. Pion, and R. Verité. 1983. Physiological basis of the protein nutrition of high producing cows. Pages 433-447 in Proc. 4th Int. Symp. Protein Metabolism and Nutrition. Institut National de la Recherche Agronomique, Paris, France.
Komaragiri, M. V. S., and R. A. Erdman. 1997. Factors affecting body tissue mobilization in early lactating dairy cows: 1 . Effect of dietary protein on mobilization of body fat and protein. J. Dairy Sci. 80:929-937.

Lahrssen, M. 1988. Changes in body composition of lactating sows and efficiency of utilization of protein and energy for milk. Ph.D. Dissertation, Freie Universitat, Berlin, Germany.

Liao, J. J. Z. 2003. An improved concordance correlation coefficient. Pharm. Stat. 2:253-261.

Lin, L. I.-K. 1989. A concordance correlation coefficient to evaluate reproducibility. Biometrics 45:255-268.

Littell, R. C., G. A. Milliken, W. W. Stroup, and R. D. Wolfinger. 1999. SAS System for Mixed Models. SAS Inst., Inc., Cary, NC.

Lofgreen, G. P. 1965. A comparative slaughter technique for determining net energy values with beef cattle. Pages 309-317 in Proc. Energy Metabolism, 3. Academic Press, London, UK.

Mayer, D. G., M. A. Stuart, and A. J. Swain. 1994. Regression of real-world data on model output: An appropriate overall test of validity. Agric. Syst. 45:93-104.

McNamara, J. P. 2000. Integrating the effects of genotype and nutrition on utilization of body reserved during lactation of dairy cows. Pages 353-369 in Ruminant Physiology: Digestion, Metabolism, Growth and Reproduction. P. B. Cronjé, ed. CABI Publishing, New York, NY.

Mitchell, P. L. 1997. Misuse of regression for empirical validation of models. Agric. Syst. 54:313-326.

Mitchell, P. L., and J. E. Sheehy. 1997. Comparison of predictions and observations to assess model performance: A method of empirical validation. Pages 437-451 in Applications of Systems Approaches at the Field Level. M. J. Kropff, P. S. Teng, P. K. Aggarwal, J. Bouma, B. A. M. Bouman, J. W. Jones, and H. H. Van Laar, ed. Kluwer Academic, Boston, MA.

Moe, P. W. 1981. Energy metabolism of dairy cattle. J. Dairy Sci. 64:1120-1139.

Moe, P. W., W. P. Flatt, and H. F. Tyrrell. 1972. Net energy value of feeds for lactation. J. Dairy Sci. 55:945-958.

Moe, P. W., H. F. Tyrrell, and W. P. Flatt. 1970. Partial efficiency of energy use for maintenance, lactation, body gain and gestation in the dairy cow. Pages 65-68 in Proc. Energy Metabolism of Farm Animals, 5. European Association for Animal Production, Juris Verlag, Zurich, Switzerland.

Neter, J., M. H. Kutner, C. J. Nachtsheim, and W. Wasserman. 1996. Applied Linear Statistical Models. 4th ed. McGraw-Hill, Boston, MA.

Newbold, J. R. 1994. Practical application of the metabolisable protein system. Pages 231-264 in Recent Advances in Animal Nutrition. P. C. Garnsworthy and D. J. A. Cole, ed. Nottingham University Press, Thrumpton, Nottingham, UK.

Nickerson, C. A. E. 1997. A note on "A concordance correlation coefficient to evaluate reproducibility." Biometrics 53:1503-1507.

NRC. 2000. Nutrient Requirements of Beef Cattle. Updated 7th ed. National Academy Press, Washington, DC.

NRC. 2001. Nutrient Requirements of Dairy Cattle. 7th ed. National Academy Press, Washington, DC.

NRC. 1985. Ruminant Nitrogen Usage. National Academy Press, Washington, DC.

Otto, K. L., J. D. Ferguson, D. G. Fox, and C. J. Sniffen. 1991. Relationship between body condition score and composition of ninth to eleventh rib tissue in Holstein dairy cows. J. Dairy Sci. 74:852-859.

Reynoso-Campos, O., D. G. Fox, R. W. Blake, M. C. Barry, L. O. Tedeschi, C. F. Nicholson, H. M. Kaiser, and P. A. Oltenacu. 2004. Predicting nutritional requirements and lactation performance of dual-purpose cows using a dynamic model. Agric. Syst. 80:67-83.

Ruiz, R., G. L. Albrecht, L. O. Tedeschi, G. Jarvis, J. B. Russell, and D. G. Fox. 2001. Effect of monensin on the performance and nitrogen utilization of lactating dairy cows consuming fresh forage. J. Dairy Sci. 84:1717-1727.

Ruiz, R., L. O. Tedeschi, J. C. Marini, D. G. Fox, A. N. Pell, G. Jarvis, and J. B. Russell. 2002. The effect of a ruminal nitrogen (N) deficiency in dairy cows: Evaluation of the Cornell Net Carbohy- 
drate and Protein System ruminal N deficiency adjustment. J. Dairy Sci. 85:2986-2999.

Schwager-Suter, R., C. Stricker, D. Erdin, and N. Künzi. 2001a. Net energy efficiencies of Holstein, Jersey, and Holstein-Jersey F1crosses. Anim. Sci. 72:335-342.

Schwager-Suter, R., C. Stricker, D. Erdin, and N. Künzi. 2001b. Quantification of changes in body weight and body composition scores during lactation by modelling individual energy balance and total net energy intake. Anim. Sci. 72:325-334.

Stone, W. C. 1996. Applied topics in dairy cattle nutrition: 1. Soyhulls as either a forage or concentrate replacement in early lactation Holstein dairy cattle, 2. Evaluation of the Cornell Net Carbohydrate and Protein System's metabolizable protein requirement as supply in Holstein dairy cattle, 3. In vitro effects of lipids on fermentation systems. Ph.D. Dissertation, Cornell University, Ithaca, NY.

Tedeschi, L. O. 2006. Assessment of the adequacy of mathematical models. Agric. Syst. 89:225-247.

Tedeschi, L. O., D. G. Fox, and T. P. Tylutki. 2003. Potential environmental benefits of ionophores in ruminant diets. J. Environ. Qual. $32: 1591-1602$.
Tennant, C. J., J. C. Spitzer, W. C. Bridges, Jr., and J. H. Hampton. 2002. Weight necessary to change body condition scores in Angus cows. J. Anim. Sci. 80:2031-2035.

Theil, H. 1961. Economic forecasts and policy. Pages 6-48 in Contributions to Economic Analysis. 2nd ed. R. Strotz, J. Tinbergen, P. J. Verdoorn and H. J. Witteveen, ed. North-Holland Publishing Company, Amsterdam, The Netherlands.

Tylutki, T. P., and D. G. Fox. 2005. The Cornell Net Carbohydrate and Protein System: An evolving model. J. Dairy Sci. 88(Suppl. 1):391. (Abstr.)

Van Saun, R. J., S. C. Idleman, and C. J. Sniffen. 1993. Effect of undegradable protein amount fed prepartum on postpartum production in first lactation Holstein cows. J. Dairy Sci. 76:236-244.

Vermorel, M., and H. Bickel. 1980. Utilisation of feed energy by growing ruminants. Ann. Zootechnie. 29:127-143.

Wildman, E. E., G. M. Jones, P. E. Wagner, R. L. Boman, H. F. Trout, Jr., and T. N. Lesch. 1982. A dairy cow condition scoring system and its relationship to selected production characteristics. J. Dairy Sci. 65:495-503.

Williams, C. B., P. A. Oltenacu, and C. J. Sniffen. 1989. Refinements in determining the energy value of body tissue reserves and tissue gains from growth. J. Dairy Sci. 72:264-269. 